Volume 2 Nomor 2, Desember 2019

E-ISSN : 2655-7347

(STUDI PUTUSAN: PUTUSAN MAHKAMAH AGUNG NOMOR 2430K/PDT/2018)

\title{
KEPASTIAN HUKUM KEPEMILIKAN SURAT IZIN GANGGUAN BIDANG \\ USAHA MUSIC ENTERTAINMENT ATAU MUSIC STADIUM DITINJAU \\ BERDASARKAN PERATURAN GUBERNUR NOMOR 101 TAHUN 2013 (STUDI PUTUSAN: PUTUSAN MAHKAMAH AGUNG NOMOR \\ 2430K/PDT/2018)
}

\author{
Indi Bintang \\ (Mahasiswa Program S1 Fakultas Hukum Universitas Tarumanagara) \\ (E-mail: indibintang@gmail.com)
}

\begin{abstract}
Dr. Ahmad Redi, S.H., M.H
(Dosen Fakultas Hukum Universitas Tarumanagara. Meraih Sarjana Hukum pada Fakultas Hukum Universitas Diponegoro, Magister Hukum pada Fakultas Hukum Universitas Indonesia, Doktor (Dr.) pada Fakultas Hukum Universitas Indonesia)

(E-mail: ahmadr@fh.untar.ac.id)
\end{abstract}

\begin{abstract}
One of legal issue of business licensing occur in the Supreme Court Decision Number 2430 K/Pdt/2018 which basically contains a civil dispute between the Management of PT Wahana Agung Indonesia Propertindo (WAIP) with PT Mata Elang International Stadium (MEIS). In the judge's legal considerations, PT MEIS was declared default because during the holding of the concert / event in the room rented from PT WAIP, they still didn/t have the nuisance permit. But in their legal considerations, the Panel of Judges wasn't careful enough in determining the legal basis. Then how is the legal certainty regarding to the possession of the nuisance permit in the field of music stadium business? How does the Government play a role in a way to overcoming uncertainty in the aspects of business licensing nowadays? To answer both questions, the author uses a normative research method, supported by statute approach and case approach. Legal certainty has not been achieved because there is an inaccuracy because the Panel of Judges didn't consider the Governor Regulation of the Jakarta Special Capital Region Number 101 of 2013 which is an implementation instruction from Regional Regulation of the Jakarta Special Capital Region Number 15 of 2011. wherein the Governor Regulation of the Jakarta Special Capital Region Number 101 of 2013 further stipulates the terms of business locations that require a nuisance permit and concerning the nuisance criteria referred to in both of the legal regulations, and when referring to the provisions regarding the business location and the nuisance criteria referred to, PT MEIS doesn't require an nuisance permit in conducting their business.
\end{abstract}

Keywords: business licensing law, nuisance law, music concert

\section{PENDAHULUAN}

\section{A. Latar Belakang}


Dalam dunia usaha sebagaimana yang dimaksud dalam Pasal 2 ayat (1) Peraturan Gubernur Provinsi Daerah Khusus Ibukota Jakarta Nomor 101 Nomor 2013 tentang Petunjuk Pelaksanaan Perizinan Tempat Usaha Berdasarkan Undang-Undang Gangguan (Selanjutnya disebut Pergub 101 Tahun 2013) menyebutkan bahwa setiap orang atau badan usaha yang akan melakukan kegiatan usaha wajib memiliki izin gangguan. Salah satu kegiatan usaha yang dimaksud dalam peraturan tersebut adalah kegiatan usaha dalam bidang pariwisata, contoh bidang usaha yang bergerak dalam bidang pariwisata adalah usaha di bidang MICE.

Permasalahan perizinan atas suatu kegiatan usaha sudah bukan hal yang asing lagi di telinga kita, baik permasalahan mengenai tidak adanya surat izin usaha perdagangan maupun tidak memiliki surat izin gangguan. Salah satu contoh konkrit yang penulis temui di Putusan Mahkamah Agung Nomor 2430 K/Pdt/2018 yang pada intinya memuat sengketa perdata antara Manajemen PT Mata Elang Internasional Stadium (selanjutnya disingkat PT MEIS) dengan PT Wahana Agung Indonesia Propertindo (selanjutnya disingkat PT WAIP). PT MEIS dinyatakan terbukti melakukan tindak wanprestasi (ingkar janji) karena tidak memenuhi kewajibannya sebagai Penyewa berdasarkan Pasal 6 huruf b Perjanjian Sewa Menyewa Ruangan yang menyebutkan bahwa "Pihak Kedua (PT MEIS) berkewajiban untuk selama perjanjian ini berlangsung/berlaku untuk tunduk dan mentaati semua peraturan dari yang berwajib terhadap Penyewaan Ruangan, serta menanggung segala akibat apabila Pihak Pertama (PT WAIP) mendapat teguran, gugatan, atau denda dari yang berwajib karena kelalaian Pihak Kedua”.

Dalam pertimbangan hukum hakim, PT MEIS dinyatakan wanprestasi karena selama ini sering menyelenggarakan kegiatan konser/event di ruangan yang disewa dari PT WAIP tersebut masih belum memiliki surat izin gangguan melalui amar Putusan Pengadilan Negeri Nomor 297/Pdt.G.2014/PN.Jkt.Utr yang kemudian dikuatkan oleh Putusan Pengadilan Tinggi DKI Jakarta Nomor 
629/Pdt/2016/PTDKI dan Putusan Mahkamah Agung Nomor 2430/K/PDT/2018.

Disisi lain, PT MEIS merasa tidak perlu memiliki surat izin gangguan.

Berdasarkan pada uraian latar belakang yang telah dikemukakan di atas, maka Penulis tertarik untuk mengkaji permasalahan tersebut dengan judul "Kepastian Hukum Mengenai Kepemilikan Surat Izin Gangguan Dalam Bidang Usaha Music Entertainment atau Music Stadium Berdasarkan Peraturan Gubernur Provinsi Daerah Khusus Ibukota Jakarta Nomor 101 Tahun 2013”.

\section{B. Perumusan Masalah}

Berdasarkan latar belakang yang telah diuraikan pada bagian sebelumnya, permasalahan yang hendak diteliti dalam penulisan ini adalah

1. Bagaimana kepastian hukum mengenai kepemilikan surat izin gangguan dalam bidang usaha music entertainment atau music stadium ditinjau berdasarkan Peraturan Gubernur Provinsi DKI Jakarta Nomor 101 Tahun 2013 tentang Petunjuk Pelaksanaan Perizinan Tempat Usaha Berdasarkan Undang-Undang Gangguan?

2. Bagaimana Pemerintah berperan dalam mengatasi kerancuan dan ketidakpastian hukum dalam aspek perizinan usaha?

\section{Metode Penelitian}

1. Jenis Penelitian

Jenis penelitian yang digunakan oleh Penulis adalah Jenis Penelitian Normatif yaitu penelitian hukum yang meletakkan hukum sebagai sebuah bangunan sistem norma. Sistem norma yang dimaksud adalah mengenai asas-asas, norma, kaidah dari peraturan perundang-undangan, putusan pengadilan, perjanjian serta doktrin. ${ }^{1)}$

2. Jenis Data dan Bahan Hukum

1) Mukti Fajar dan Yulianto Achmad, Dualisme Penelitian Hukum Normatif \& Empiris, (Yogyakarta: Pustaka Pelajar, 2010), hal. 153-183. 
Dalam hal Penulis menggunakan jenis penelitian normatif maka jenis data yang diperlukan adalah data sekunder. Data sekunder atau data kepustakaan terdiri dari bahan hukum berupa berbagai literatur yang dikelompokkan ke dalam:

a. Bahan Hukum Primer

Dalam penelitian ini yang menjadi bahan hukum primer ialah:

1. Undang-Undang Gangguan (hinderordonanntie) Staatsblad Nomor 226 Tahun 1926

2. Peraturan Daerah Provinsi Daerah Khusus Ibukota Jakarta Nomor 15 Tahun 2011 tentang Perizinan Tempat Usaha Berdasarkan Undang-Undang Gangguan.

3. Peraturan Daerah Provinsi Daerah Khusus Ibukota Jakarta Nomor 3 Tahun 2019

4. Peraturan Gubernur Provinsi Daerah Khusus Ibukota Jakarta Nomor 101 Tahun 2013 tentang Petunjuk Pelaksanaan Perizinan Tempat Usaha Berdasarkan Undang-Undang Gangguan

5. Putusan Pengadilan Negeri Nomor 297/Pdt.G/2014/PN.Jkt.Utr

6. Putusan Pengadilan Tinggi DKI Jakarta Nomor 629/Pdt/2016/PTDKI

7. Putusan Mahkamah Agung Nomor 2430K/PDT/2018

b. Bahan Hukum Sekunder

Dalam penelitian ini yang menjadi sumber bahan hukum sekunder adalah sebagaimana yang tercantum dalam bagian Daftar Pustaka

c. Bahan Hukum Tersier 
Merupakan bahan hukum yang dapat menjelaskan baik bahan hukum primer maupun bahan hukum sekunder, yang berupa kamus, ensiklopedi, leksikon dan lain-lain ${ }^{2)}$

3. Sifat Penelitian

Sifat yang Penulis gunakan dalam penelitian ini adalah preskriptif karena dimaksudkan untuk memberikan argumentasi terhadap Putusan Mahkamah Agung dengan nomor perkara 2430K/PDT/2018 yang dirasa tidak sesuai dengan ketentuan Pasal 4 dan 7 Pergub 101 Tahun 2013 tentang Petunjuk Pelaksanaan Perizinan Tempat Usaha Berdasarkan UndangUndang Gangguan mengenai pihak yang wajib mengajukan permohonan izin gangguan.

4. Pendekatan dalam Analisis

Dalam penelitian ini Penulis menggunakan teknik pendekatam perundang-undangan (statute approach) sebagai dasar awal dalam melakukan analisis, yang artinya dalam melakukan analisis Penulis bersandarkan pada ketentuan yang terdapat dalam Undang-Undang dalam hal ini khususnya Undang-Undang Gangguan (hinderordonanntie) Staatsblad Nomor 226 Tahun 1926, Perda 15 Tahun 2011 tentang Perizinan Tempat Usaha Berdasarkan Undang-Undang Gangguan, dan Pergub 101 Tahun 2013 tentang Petunjuk Pelaksanaan Perizinan Tempat Usaha Berdasarkan Undang-Undang Gangguan. Selain itu Penulis juga menggunakan pendekatan kasus (case approach) untuk meneliti mengenai penerapan norma dan kaidah hukum yang berlaku pada isu hukum dalam kasus yang sedang dihadapi.

\section{PEMBAHASAN}

2) Ibid., hal.159. 
Volume 2 Nomor 2, Desember 2019

E-ISSN : 2655-7347

\section{A. Konsep Kepastian Hukum dalam Penerapan Ketentuan Wajib Izin Gangguan terhadap PT Mata Elang Internasional Stadium}

Kepastian hukum dikatakan dapat tercapai apabila memenuhi beberapa hal, yakni antara lain apabila instansi-instansi penguasa (pemerintahan) menerapkan aturan-aturan hukum tersebut secara konsisten dan juga tunduk dan taat terhadapnya, selain itu juga apabila hakim-hakim (peradilan) yang mandiri dan tidak berpihak menerapkan aturan-aturan hukum tersebut secara konsisten sewaktu mereka menyelesaikan sengketa hukum. ${ }^{3)}$ Melalui penjelasan tersebut, dapat kita ketahui bahwa untuk mencapai kepastian hukum, baik pemerintah maupun hakim harus berlaku konsisten dan tunduk terhadap setiap peraturan hukum yang berlaku di Indonesia, konsisten dalam artian bahwa apa bunyi peraturan hukumnya, itulah yang diterapkan. Dan dalam melakukan penerapan peraturan hukum, peraturan hukum tersebut haruslah dicermati dan dimengerti baik-baik supaya penerapan nya dapat sesuai dengan maksud dan cita-cita dibentuknya peraturan hukum tersebut.

Ketidakcermatan Majelis Hakim yang dalam pertimbangan hukumnya hanya mengacu pada Pasal 2 dan Pasal 6 Perda 15 Tahun 2011, dan tidak mengindahkan hadirnya Pergub 101 Tahun 2013 sebagai petunjuk pelaksanaan dari Perda 15 Tahun 2011, menurut hemat penulis telah menimbulkan ketidakpastian hukum dalam menjatuhkan putusan pada kasus terkait. Oleh karena kepastian hukum dapat tercapai abaila aturan-aturan hukum dapat diterapkan secara konsisten. Konsisten dalam artian bahwa apa bunyi peraturan hukumnya, itulah yang diterapkan. Sehingga penerapan hukumnya dapat sesuai dengan cita-cita dibentuknya peraturan hukum tersebut. Apabila Majelis Hakim yang terhomat mempertimbangkan Pergub 101 Tahun 2013, mungkin akan menghasilkan hasil pertimbangan dan tentunya amar putusan yang berbeda.

\footnotetext{
3) Jan Michiel Otto, Kepastian Hukum di Negara Berkembang, (Jakarta: Komisi Hukum Nasional Republik Indonesia, 2003)
} 
Pasal 5 Pergub 101 Tahun 2013, mengatur lebih lanjut mengenai lokasi tempat usaha yang memerlukan izin gangguan, seperti; lokasi tempat usaha yang terletak di jalan arteri, jalan kolektor, jalan lokal, atau jalan lingkungan, yang berada di kawasan industri, kawasan pusat perdagangan dan jasa, atau kawasan permukiman. Oleh karena lokasi PT MEIS berada dalam kawasan wisata terpadu, yang dimana tidak termasuk di dalam kawasan industri, kawasan permukiman, maupun kawasan pusat perdagangan dan jasa sebagaimana yang disebutkan di dalam Pasal 5 Pergub 101 Tahun 2013, terlebih, kawasan wisata terpadu pada hakikatnya memang diperuntukkan untuk kegiatan hiburan maka menurut hemat penulis dapat disimpulkan bahwa PT MEIS bukanlah tempat usaha/kegiatan usaha yang memerlukan izin gangguan jika ditinjau berdasarkan lokasi nya.

Kriteria gangguan yang dimaksud dalam pemberian izin gangguan terhadap tempat usaha/kegiatan usaha diatur dalam Pasal 7 sampai dengan Pasal 16 Pergub 101 Tahun 2013. Menurut Pasal 7 Pergub 101 Tahun 2013, kriteria gangguan dalam pemberian izin gangguan didasarkan atas intensitas atau lama gangguan dan sumber gangguan terhadap:
a. lingkungan;
b. sosial kemasyarakatan; dan/atau
c. ekonomi.

Pasasl 8 Pergub 101 Tahun 2013 menjelaskan mengenai gangguan terhadap lingkungan sebagaimana yang dimaksud dalam Pasal 7 huruf a, yaitu adalah gangguan akibat dari tempat usaha dan/atau kegiatan usaha terhadap:
a. Fungsi tanah;
b. Air tanah;
c. Sungai/kanal/drainase;
d. Waduk/situ;
e. Laut;
f. Udara; dan/atau 
Volume 2 Nomor 2, Desember 2019

E-ISSN : 2655-7347

g. Getaran dan/atau kebisingan.

Setelah melakukan penelitian terhadap kegiatan usaha PT MEIS dan melakukan analisa terhadap Pasal 9 sampai dengan Pasal 14 yang merupakan indikator gangguan terhadap lingkungan, Penulis tidak menemukan adanya faktorfaktor dari kegiatan usaha PT Mata Elang Internasional yang dapat menimbulkan gangguan terhadap lingkungan. Dengan pertimbangan sebagai berikut:

a. Kegiatan usaha PT MEIS tidak berpotensi menimbulkan gangguan terhadap fungsi tanah karena dalam menjalankan kegiatan usaha nya PT MEIS tidak memanfaatkan ruang bawah tanah untuk dijadikan tempat usaha maupun untuk menunjang kegiatan usaha nya.

b. Kegiatan usaha PT MEIS tidak berpotensi menimbulkan gangguan terhadap air tanah karena dalam menjalankan kegiatan usaha nya yang bergerak dalam penyewaan ruang untuk kegiatan hiburan, penggunaan air bukanlah menjadi faktor primer dalam menjalankan usaha nya. Selain itu, oleh karena kedudukan PT MEIS hanyalah sebagai penyewa maka kebutuhan akan air, misalnya air yang dipakai untuk toilet, disediakan oleh pihak Ancol Beach City (PT WAIP)

c. Kegiatan usaha PT MEIS tidak berpotensi menimbulkan gangguan terhadap sungai/kanal/drainase dan waduk/situ karena dalam menjalankan kegiatan usaha nya tidak dapat dibuktikan bahwa kegiatan usaha nya menimbulkan limbah cair dan/atau meningkatkan pencemaran air.

d. Kegiatan usaha PT MEIS tidak berpotensi menimbulkan gangguan terhadap laut karena dalam menjalankam kegiatan usaha nya PT MEIS tidak berhubungan baik secara langsung maupun tidak langsung dengan laut, sehingga menurut hemat penulis hampir dapat dipastikan bahwa kegiatan usaha nya tidak akan mengakibatkan pencemaran terhadap air laut maupun gangguan terhadap terumbu karang seperti yang dijelaskan pada Pasal 12 Pergub 101 Tahun 2013. 
e. Kegiatan usaha PT MEIS tidak berpotensi menimbulkan gangguan terhadap udara karena tidak memenuhi faktor-faktor gangguan terhadap udara sebagaimana yang telah dijelaskan pada Pasal 13 Pergub 101 Tahun 2013, dimana PT MEIS tidak membangun gedung melainkan hanya menyewa berupa sebuah ruangan di dalam Ancol Beach City, tidak membangun jembatan penghubung gedung, juga tidak menghasilkan zat, energy, dan/atau komponen lain ke dalam udara yang dapat menyebabkan pencemaran udara.

f. Kegiatan usaha PT MEIS tidak berpotensi menimbulkan gangguan terhadap getaran dan/atau kebisingan karena walaupun dalam menjalankan kegiatan usaha nya, PT MEIS paling banyak menerima penyelenggaraan konser musik, dimana pasti menimbulkan suara-suara dan keramaian, namun arti dari getaran dan/atau kebisingan yang dimaksud mengganggu lingkungan adalah getaran dan/atau kebisingan yang diakibatkan sarana yang digunakan untuk usaha seperti mesin produksi, mesin uap.

Selanjutnya mengenai gangguan sosial kemasyarakatan yang dimaksud dalam

Pasal 7 huruf b Pergub 101 Tahun 2013, dijelaskan lebih lanjut dalam Pasal 15 Pergub 101 Tahun 2013.

$\underline{\text { Pasal } 15}$

(1) Gangguan terhadap sosial kemasyarakatan sebagaimana dimaksud dalam Pasal 7 huruf b, merupakan ancaman terhadap:

a. Kehidupan masyarakat setempat; dan/atau

b. Ketertiban umum

(2) Gangguan menjadi ancaman terhadap kehidupan masyarakat setempat sebagaimana dimaksud pada Ayat (1) huruf a, menghambat atau mengurangi kegiatan sosial dan budaya masyarakat setempat baik langsung maupun tidak langsung akibat kegiatan usaha.

(3) Gangguan menjadi ancaman ketertiban umum sebagaimana dimaksud pada ayat (1) huruf $b$, antara lain terganggunya ketertiban masyarakat)

Pertama, dalam kasus PT MEIS, lokasi tempat usaha nya adalah di dalam kawasan wisata, yang memang pada hakikatnya diperuntukkan untuk kegiatan hiburan, terlebih PT MEIS hanya menyewa sebagian dari bangunan Ancol Beach 
City. Setelah melakukan wawancara dan survey lapangan, memang betul keterangan dari Bapak Dr. Hj. Henry Yosodiningrat S.H., M.H bahwa di sekitaran Ancol Beach City tidak terdapat permukiman warga, melainkan hanya lapangan kosong, pantai, dan kuburan. Sehingga menurut hemat Penulis, kemungkinan kegiatan usaha PT MEIS menimbulkan gangguan terhadap kehidupan masyarakat setempat maupun ketertiban umum hampir nihil.

Kedua, dalam menyelenggarakan sebuah event yang menghadirkan massa mulai dari 300 (tiga ratus) sampai dengan lebih dari 1000 (seribu) orang, bagi event organizer dari event tersebut diwajibkan mengurus izin keramaian sebelum menyelenggarakan event yang dimaksud, yang persyaratan nya diatur dalam Juklap Kapolri No. Pol / 02 / XII / 95 tentang Perijinan dan Pemberitahuan Kegiatan Masyarakat. Adapun tujuan dari diperlukannya izin keramaian ini adalah untuk menjaga keamanan dan ketertiban setiap individu baik yang terlibat secara langsung maupun tidak langsung selama penyelenggaraan event tersebut, dalam hal pengadaan konser musik, izin keramaian diperuntukkan untuk menjaga keamanan dan ketertiban baik penonton konser maupun masyarakat umum yang berada di sekitar wilayah tempat berlangsungnya konser tersebut. Maka menurut hemat Penulis, izin keramaian yang sudah diurus oleh event organizer setiap saat akan diselenggarakannya sebuah kegiatan, sudah dapat menjadi payung perlindungan bagi masyarakat umum bahwa penyelenggara dan penanggungjawab dari kegiatan tersebut beritikad baik untuk menjaga keamanan dan ketertiban umum.

Ketiga, dalam hal dikhawatirkan kegiatan usaha PT MEIS dapat menghambat atau mengurangi kegiatan sosial dan budaya masyarakat setempat sesuai Pasal 15 ayat (2) Pergub 101 Tahun 2013, menurut hemat Penulis diperlukan penjelasan lebih lanjut mengenai Pasal ini, misalnya mengenai bagaimana cara pembuktian bahwa kegiatan usaha tersebutlah yang menghambat dan mengurangi kegiatan sosial dan budaya masyarakat setempat, perlu ditetapkan apa tolok ukur nya. 
Selanjutnya mengenai gangguan terhadap ekonomi yang dimaksud dalam Pasal 7 huruf c Pergub 101 Tahun 2013, dijelaskan lebih lanjut dalam Pasal 16 Pergub 101 Tahun 2013.

$\underline{\text { Pasal } 16}$

Gangguan terhadap ekonomi sebagaimana dimaksud dalam Pasal 7 huruf c, merupakan ancaman terhadap:

a. penurunan produksi usaha masyarakat sekitar; dan /atau

b. penurunan nilai ekonomi benda tetap dan benda bergerak yang berada di sekitar lokasi usaha)

Menurut hemat Penulis, kegiatan usaha PT MEIS tidak memenuhi kriteria bidang usaha yang memiliki intensitas atau yang dapat menjadi sumber gangguan terhadap ekonomi dengan pertimbangan bahwa kegiatan usaha PT MEIS merupakan penyewaan gedung untuk menyelenggarakan acara, yang paling banyak digunakan untuk kegiatan konser musik. Dimana acara-acara ini tidak berlangsung setiap hari, dan juga tidak menggunakan mesin produksi atau menimbulkan gangguan lain yang dapat menurunkan produksi usaha masyarakat sekitar, juga tidak berpengaruh terhadap nilai ekonomi benda tetap dan benda bergerak yang berada di sekitar lokasi usaha, justru sebaliknya, pada realitanya setiap saat diselenggarakan acara di Mata Elang Internasional Stadium, masyarakat sekitar banyak diuntungkan karena dapat berjualan di sekitaran area Ancol Beach City. Terlebih dengan banyaknya turis mancanegara, masyarakat sekitar dapat memproduksi baik makanan maupun cinderamata khas Indonesia dan dapat dijual dengan harga yang lebih tinggi kepada turis-turis tersebut.

Hal lain yang dapat dipertimbangkan menurut hemat Penulis, terdapat ketidakjelasan dalam cara membuktikan bahwa suatu kegiatan usaha dapat menurunkan produksi masyarakat sekitar dan dapat menurunkan nilai ekonomi barang bergerak maupun tidak bergerak seperti yang dijelaskan dalam Pasal 16 Pergub 101 Tahun 2013, misalnya apakah perlu dilakukan proses audit dulu sebelumnya terhadap usaha masyarakat yang bersangkutan. 
PT MEIS telah menjalankan kegiatan usaha nya dalam bidang music entertainment atau music stadium sekitar kurang lebih 28 (dua puluh delapan) bulan / 2 (dua) tahun hingga mendapat Berita Acara Pemeriksaan mengenai ketiadaan izin usaha berdasarkan Undang-Undang Gangguan (Hinderordonnantie) pada tanggal 9 Juni 2014. Waktu 2 (dua) tahun bukanlah waktu yang singkat menurut Penulis. Selama kurun waktu 2 (dua) tahun itu pula sudah terlaksana banyak event baik yang bertaraf nasional maupun internasional di dalam Mata Elang Internasional Stadium. Dilansir melalui situs Wikipedia, dalam kurun waktu 2 (dua) tahun tersebut tercatat 37 (tiga puluh tujuh) event konser musik terlaksana di Mata Elang Internasional Stadium).

Menurut hemat Penulis, Badan dan/atau Pejabat Pemerintahan yang dalam hal ini adalah Satpol PP, gagal dalam menerapkan salah satu asas umum pemerintahan yang baik yaitu asas pelayanan yang baik) Adapun asas pelayanan yang baik dapat diwujudkan dengan memberikan pelayanan yang tepat waktu, prosedur dan biaya yang jelas, sesuai dengan standar pelayanan, dan ketentuan peraturan perundangundangan.

Disisi lain jika dilihat berdasarkan sifatnya, Izin Gangguan bersifat terikat, yang artinya penerbitan izin gangguan terikat pada aturan dan hukum tertulis serta organ yang berwenang dalam izin kadar kebebasannya dan wewenangnya tergantung pada kadar sejauh mana peraturan perundang-undangan mengaturnya) Dari pengertian tersebut dapat kita pahami bawa wewenang Satpol PP dalam melakukan penerapan izin gangguan terhadap suatu kegiatan usaha haruslah sesuai dan dibatasi dengan bunyi teks perundang-undangan yang mengaturnya.

Saat ini realisasi pendapatan pajak DKI Jakarta baru mencapai 79,29\% (tujuh puluh sembilan koma dua puluh sembilan persen) atau Rp 35.300.000.000.000,(tiga puluh lima triliun tiga ratus miliar rupiah) dari target Rp 44.500.000.000.000,(empat puluh empat triliun lima ratus miliar rupiah). Sementara itu, untuk pajak hiburan realisasinya baru mencapai Rp 743.000.000.000 (tujuh ratus empat puluh 
tiga miliar rupiah) atau $87 \%$ (delapan puluh tujuh persen) dari target $\mathrm{Rp}$ 850.000.000.000 (delapan ratus lima puluh miliar rupiah). Untuk mendongkrak pajak hiburan, Pemprov DKI Jakarta berencana membangun tempat eksibisi yang multifungsi. ${ }^{4)}$

Di Jakarta sendiri, dapat dikatakan hampir semua hotel berbintang 3 (tiga) ke atas, memiliki multifunction hall nya sendiri, yang biasanya dapat digunakan untuk kegiatan rapat pertemuan kantor maupun penyelenggaraan pernikahan. Namun untuk tempat penyelenggaraan MICE yang bertaraf internasional, Indonesia termasuk di Jakarta dinilai masih kekurangan tempat, hal ini menjadi salah satu faktor mengapa kegiatan-kegiatan MICE di Indonesia yang bertaraf internasional masih belum mencapai target. Ketua Umum DPP Asosiasi Perusahaan Pameran Indonesia (Asperapi) Effi Setiabudi berpendapat, saat ini 90\% (sembilan puluh persen) kegiatan MICE di Indonesia masih berskala nasional dan hanya $10 \%$ (sepuluh persen) yang bertaraf internasional. Sedangkan pada tahun ini, Kementerian Pariwisata telah menargetkan pertumbuhan industri MICE meningkat dari 6\% (enam persen) pada 2018 menjadi 10\% (sepuluh persen) pada tahun 2019. ${ }^{5 \text { ) }}$

Salah satu event bertaraf internasional yang paling memungkinkan untuk diselenggarakan di Jakarta adalah konser musik. Jakarta merupakan pusat pemerintahan dan pusat perekonomian di Indonesia, dimana hal ini berpotensi menjadi daya tarik yang besar bagi promotor untuk mengadakan konser musik dengan mendatangkan artis internasional ke Jakarta. Hal ini juga dapat menarik wisatawan-wisatawan mancanegara untuk datang ke Jakarta, khususnya bagi wisatawan mancanegara yang masih di daerah Asia. Kedatangan wisatawanwisatawan tersebut yang niat awalnya untuk menonton konser musik, dapat

4) Ramdani, "DWP Pindah ke Bali DKI Kehilangan 6 Miliar" https://mediaindonesia.com/read/detail/273945-dwp-pindah-ke-bali-dki-kehilangan-rp6-miliar, 19 Desember 2019, hal. 1

5 ) Yenita Petriella, "Indonesia Kekurangan Tempat MICE Berstandar Internasional" https://ekonomi.bisnis.com/read/20190214/12/888875/indonesia-kekurangan-tempat-mice-berstandarinternasional, 19 Desember 2019, hal. 1. 
berpotensi menimbulkan keuntungan untuk sektor lain juga, tidak menutup kemungkinan wisatawan-wisatawan tersebut ingin menghabiskan pekannya menjelajahi keindahan Jakarta dan/atau Indonesia.

Besarnya pengaruh konser musik internasional terhadap pendapatan negara menjadi pertimbangan mengapa pembangunan tempat penyelenggaraan konser harus di optimalkan, khususnya yang bertaraf internasional, dengan kapasitas atau daya tampung pengunjung yang besar. Nama Mata Elang sudah tidak perlu diragukan lagi kiprah nya di dunia penyelenggaraan event, khususnya dalam hal pengadaan dan perancangan konsep sound system, lighting, rigging, panggung, dan lain lain. Dan Mata Elang Internasional Stadium merupakan music stadium pertama yang dirancang khusus dengan standar internasional untuk penyelenggaraan konser musik. Banyak pihak yang menyayangkan ditutupnya Mata Elang Internasional Stadium. Salah satunya adalah personil band Slank yang bernama Abdee. Penutupan Mata Elang Internasional Stadium bagi Abdee Slank merupakan tamparan bagi pekerja seni musik, terlebih karena di Indonesia sangat langka tempat penyelenggaraan musik bertaraf internasional. "Di Indonesia belum ada gedung pertunjukan yang dirancang khusus kecuali Mata Elang Internasional Stadium, terlebih daya tampungnya bisa mencapai lebih dari 10.000 (sepuluh ribu) orang. Jadi, ya sayang banget kalau ditutup." begitu paparnya. ${ }^{6)}$

\section{B. Peran Pelayanan Perizinan Berusaha Terintegrasi Secara Elektronik dalam Mengatasi Kerancuan dan Ketidakpastian Hukum dalam Aspek Perizinan Usaha}

Salah satu tujuan Negara Indonesia dalam Pembukaan Undang-undang Dasar 1945 adalah untuk memajukan kesejahteraan umum. Kesejahteraan umum ini

\footnotetext{
6 ) Administrator, "MEIS Ditutup Tamparan Buat Pekerja Seni Musik", http://tabloidkabarfilm.com/berita/258/meis-ditutup,-tamparan-buat-pekerja-seni- $\quad$ musik.html, 19 Desember 2019, hal. 1.
} 
seyogyanya dapat diperoleh dengan adanya peningkatan perekonomian bagi seluruh warga masyarakatnya secara merata. Dalam rangka mencapai tujuan tersebut, Indonesia sebagai negara berkembang haruslah terus melakukan peningkatan ekonomi dan melakukan pembangunan di berbagai wilayah. Salah satu upaya penting yang dilakukan Pemerintah Indonesia untuk meningkatkan perekonomian negara adalah dengan membuka diri terhadap investasi yang masuk ke dalam negara.

Salah satu jenis perizinan yang dikeluarkan oleh Pemerintah sebagai salah satu persyaratan untuk berinvestasi adalah izin gangguan (hinderordonanntie), yang dimana pengertian nya sendiri adalah sebagai pemberian izin tempat usaha/kegiatan kepada orang pribadi atau badan di lokasi tertentu yang dapat menimbulkan bahaya, kerugian, dan gangguan, tidak termasuk tempat usaha/kegiata yang telah ditentukan oleh Pemerintah Pusat atau Pemerintah Daerah. Memandang uraian pengertian tersebut, dapat disimpulkan bahwa sebenarnya izin gangguan merupakan izin tempat usaha/kegiatan yang ditujukan untuk melindungi masyarakat sekitar atas dampak berdirinya suatu tempat usaha dari kemungkinan timbulnya bahaya kerugian maupun bahaya gangguan.

Meskipun memiliki tujuan yang baik, namun dalam pelaksanaannya pengurusan izin usaha berdasarkan undang-undang gangguan masih memerlukan waktu yang cukup lama sehingga membuat pelaku usaha tidak dapat segera memulai aktivitas usahanya. Padahal dalam dunia usaha, faktor waktu kerap kali dapat mempengaruhi nilai keuntungan dan kerugian yang diperoleh oleh pelaku usaha. Apabila ditinjau lebih lanjut, masih lamanya pengurusan izin gangguan dipengaruhi juga oleh faktor-faktor banyaknya persyaratan yang harus dipenuhi dan proses pengurusan dari masing-masing persyaratan yang masih berbelit-belit, sehingga memakan waktu yang cukup lama. Faktor lainnya yang patut dipertimbangkan adalah perihal koordinasi dengan instansi pemerintah maupun pihak-pihak terkait lainnya yang belum tentu selalu dapat berjalan dengan lancar. Faktor-faktor ini 
secara garis besar dapat mempengaruhi minat investor yang hendak menanamkan modalnya.

Dalam beberapa kasus, termasuk sebagai contohnya adalah dalam kasus PT MEIS, ketidakpastian dan kemungkinan adanya biaya yang besar dalam pengurusan izin dapat membuat investor membatalkan rencana investasi, bahkan apabila usaha mereka sendiri pun mungkin tidak menimbulkan gangguan yang berarti.

Menteri Dalam Negeri Republik Indonesia sesuai dengan kewenangannya telah melakukan evaluasi terhadap perizinan gangguan dengan mengeluarkan Peraturan Menteri Dalam Negeri Nomor 19 Tahun 2017 tentang Pencabutan Peraturan Menteri Dalam Negeri Nomor 27 Tahun 2009 tentang Pedoman Penetapan Izin Gangguan di Daerah. Oleh karena itu dibutuhkan harmonisasi dasar hukum antara pusat dan daerah terhadap pelaksanaan izin usaha berdasarkan undang-undang gangguan.

Oleh karena alasan urgensitas tersebut, Pada tanggal 17 September 2019, ditetapkanlah Peraturan Daerah Provinsi Daerah Khusus Ibukota Jakarta Nomor 3 Tahun 2019 tentang Pencabutan Peraturan Daerah Nomor 15 Tahun 201 tentang Perizinan Tempat Usaha Berdasarkan Undang-Undang Gangguan. Dengan dicabutnya Perda 15 Tahun 2011 maka Pergub 101 Tahun 2013 yang merupakan petunjuk pelaksanaan dari Perda 15 Tahun 2011 juga ikut tidak berlaku lagi. Secara tidak langsung, alasan dicabutnya Perda 15 Tahun 2011 adalah untuk memudahkan proses berusaha dan/atau berinvestasi di Indonesia, khususnya di wilayah DKI Jakarta.

Pada saat ini, Pemerintah Indonesia telah melakukan trobosan baru dalam rangka usaha meningkatkan perekonomian negara, dengan cara memberikan kemudahan bagi para pelaku usaha yang hendak memulai dan menjalankan usaha nya baik usaha mikro, kecil, menengah, maupun besar. Upaya ini terwujud dalam lahirnya Peraturan Pemerintah Nomor 24 Tahun 2018 (selanjutnya disingkat PP 24 Tahun 2018) tentang Pelayanan Perizinan Berusaha Terintegrasi Secara Elektronik. 
Menurut Pasal 1 ayat (5) PP 24 Tahun 2018, Perizinan Berusaha Terintegrasi Secara Elektronik atau Online Single Submission yang selanjutnya disingkat OSS adalah Perizinan Berusaha yang diterbitkan oleh Lembaga OSS untuk dan atas nama menteri, pimpinan lembaga, gubernur, atau bupati/wali kota kepada Pelaku Usaha melalui sistem elektronik yang terintegrasi.

Dilansir melalui Pedoman Perizinan Usaha Berdasarkan OSS untuk Pelaku Usaha yang diterbitkan oleh Kementerian Koordinator Bidang Perekonomian Republik Indonesia, pihak-pihak yang dapat menggunakan OSS dalam proses perizinan berusaha adalah setiap pelaku usaha dengan karakteristik sebagai berikut:

1. Berbentuk badan usaha maupun perorangan;

2. Usaha mikro, kecil, menengah maupun besar;

3. Usaha perorangan/badan usaha baik yang baru maupun yang sudah berdiri sebelum operasionalisasi OSS;

4. Usaha dengan modal yang seluruhnya berasal dari dalam negeri, maupun terdapat komposisi modal asing.

Sedangkan manfaat dari penerapan sistem OSS ini bagi para pelaku usaha antara lain sebagai berikut:

1. Mempermudah pengurusan berbagai perizinan berusaha baik prasyarat untuk melakukan usaha (izin terkait lokasi, lingkungan, dan bangunan), izin usaha, maupun izin operasional untuk kegiatan operasional usaha di tingkat pusat ataupun daerah dengan mekanisme pemenuhan komitmen persyaratan izin

2. Memfasilitasi pelaku usaha untuk terhubung dengan semua stakeholder dan memperoleh izin secara aman, cepat dan real time

3. Memfasilitasi pelaku usaha dalam melakukan pelaporan dan pemecahan masalah perizinan dalam satu tempat

4. Memfasilitasi pelaku usaha untuk menyimpan data perizinan dalam satu identitas berusaha (NIB) 
Diharapkan dengan adanya sistem baru yang sudah lebih efektif dan efisien dapat memberikan kemudahan bagi para pelaku usaha dan/atau investor untuk memulai usaha nya di Indonesia, khususnya di DKI Jakarta, sehingga hal ini dapat mendorong naiknya perekonomian negara demi mewujudkan kesejahteraan umum sesuai dengan tujuan Negara Indonesia dalam Pembukaan Undang-Undang Dasar Republik Indonesia Tahun 1945.

\section{PENUTUP}

\section{A. Kesimpulan}

Kepastian hukum dalam penerapan ketentuan izin gangguan dalam kasus ini belum tercapai oleh karena instansi-instansi yang terkait beserta Majelis Hakim yang mandiri dan tidak berpihak belum menerapkan aturan hukum sesuai dengan bunyi nya, sehingga penerapan peraturan hukum tersebut belum sesuai dengan cita-cita dibentuknya peraturan hukum tersebut. Hal ini juga menunjukkan bahwa perizinan yang diterapkan di DKI Jakarta belum terintegrasi dengan baik terkait penegakkannya,

Kerugian akibat ditutupnya PT MEIS membawa kerugian secara tidak langsung bagi DKI Jakarta karena kehilangan salah satu tempat penyelenggaraan MICE taraf internasional dengan kapasitas yang besar serta kualitas yang tidak perlu diragukan lagi, sedangkan DKI Jakarta sendiri hingga saat ini masih kekurangan tempat penyelenggaraan MICE yang memadai, padahal dengan beroperasi nya Mata Elang Internasional Stadium dapat mendongkrak pendapatan pajak hiburan DKI Jakarta, yang jangka panjangnya dapat membawa dampak positif terhadap pertumbuhan ekonomi Negara. Salah satu upaya penting yang dilakukan Pemerintah Indonesia untuk meningkatkan perekonomian Negara adalah dengan membuka diri terhadap investasi yang masuk. Salah satu jenis perizinan yang dikeluarkan oleh Pemerintah sebagai persyaratan untuk berinvestasi adalah izin gangguan (hinderordonanntie), meskipun memiliki 
Volume 2 Nomor 2, Desember 2019

E-ISSN : 2655-7347

tujuan yang baik, namun dalam pelaksanaannya pengurusan izin usaha berdasarkan undang-undang gangguan masih menimbulkan berbagai kontra terutama dalam hal kepastian tempat usaha-usaha mana saja yang membutuhkan izin tersebut. Dalam beberapa kasus, termasuk sebagai contohnya adalah dalam kasus PT MEIS, ketidakpastian, proses perizinan yang cukup rumit, dan kemungkinan adanya biaya yang besar dalam pengurusan izin dapat membuat investor membatalkan rencana investasi, bahkan apabila usaha mereka sendiri pun mungkin tidak menimbulkan gangguan yang berarti.

Pemerintah Indonesia telah melakukan upaya trobosan baru dalam rangka memberikan kemudahan dalam proses berbisnis (ease of doing business) dan/atau berinvestasi di Indonesia untuk meningkatkan perekonomian Negara, upaya ini terwujud dalam lahirnya Peraturan Pemerintah Nomor 24 Tahun 2018 tentang Pelayanan Perizinan Berusaha Terintegrasi Secara Elektronik (Sistem Online Single Submission). Sistem OSS diharapkan dapat lebih efektif dan efisien sehingga sanggup memberikan kemudahan bagi para pelaku usaha dan/atau investor untuk memulai usaha nya di Indonesia, khususnya di DKI Jakarta, sehingga hal ini dapat mendorong naiknya perekonomian Negara.

\section{B. Saran}

Saran bagi pemerintah, baiknya tiap instansi Tata Usaha Negara, dalam hal ini khususnya instansi yang terkait dengan perizinan berusaha, agar kedepannya dapat lebih mengamalkan asas umum pelayanan yang baik, misalnya dalam hal pengawasan serta penerapan setiap produk hukum Tata Usaha Negara. Para penegak hukum yang terlibat harus memahami betul isi dari peraturan yang bersangkutan sehingga tidak terjadi salah sasaran dalam proses penerapan izin berusaha, sehingga tujuan dari dibentuknya peraturan tersebut dapat efektif terlaksana sesuai cita-citanya. Mengingat besarnya pengaruh industri MICE terhadap pendapatan Negara, dan salah satu bentuk kegiatan nya yang paling memungkinkan untuk diselenggarakan adalah dalam hal penyelenggaraan konser 
Volume 2 Nomor 2, Desember 2019

E-ISSN : 2655-7347

musik internasional, hendaknya para Pejabat pemerintahan dan segenap jajaran nya lebih mendukung setiap pihak yang berkontribusi dalam penyelanggaraan kegiatan tersebut, salah satu bentuk dukungan yang dapat diamalkan adalah dalam hal mempermudah proses pemberian izin yang dibutuhkan oleh pihak venue maupun promotor, karena fakta yang terjadi hingga saat ini, masih terdapat oknum-oknum dengan itikad kurang baik yang memanfaatkan pihak promotor untuk mendapatkan keuntungan, contohnya harus memberikan sejumlah uang tertentu sebagai pelancar agar izin keramaian dapat diterbitkan.

Saran bagi para praktisi hukum, kaum akademis, dan pelaku usaha, hendaknya lebih cermat serta mengamalkan prinsip kehati-hatian dalam melaksanakan kewajiban terkait kewajiban izin berusaha. Dengan lahirnya sistem perizinan berusaha yang sudah terintegrasi dengan baik dan sejalan dengan konsep kemudahan berbisnis di Indonesia (ease of doing business), serta didukung oleh minat para pelaku usaha dan investor untuk memulai usaha nya di Indonesia, diharapkan dapat membantu meningkatkan perekonomian Negara.

\section{DAFTAR PUSTAKA}

\section{A. Buku}

Achmad, Yulianto. dan Mukti Fajar. Dualisme Penelitian Hukum Normatif \& Empiris. (Yogyakarta: Pustaka Pelajar, 2010).

Michiel, Jan Otto. Kepastian Hukum di Negara Berkembang, (Jakarta: Komisi Hukum Nasional Republik Indonesia, 2003).

\section{B. Website}

Administrator, "MEIS Ditutup Tamparan Buat Pekerja Seni Musik", http://tabloidkabarfilm.com/berita/258/meis-ditutup,-tamparan-buatpekerja-seni- musik.html. Diakses tanggal 19 Desember 2019.

Ramdani, "DWP Pindah ke Bali DKI Kehilangan 6 Miliar" https://mediaindonesia.com/read/detail/273945-dwp-pindah-ke-balidki-kehilangan-rp6-miliar. Diakses tanggal 19 Desember 2019. 


\section{Jurnal Huknm Adigamä}

Volume 2 Nomor 2, Desember 2019 E-ISSN : 2655-7347
KEPASTIAN HUKUM KEPEMILIKAN SURAT IZIN GANGGUAN BIDANG USAHA MUSIC ENTERTAINMENT ATAU MUSIC STADIUM DITINJAU BERDASARKAN PERATURAN GUBERNUR NOMOR 101 TAHUN 2013 (STUDI PUTUSAN: PUTUSAN MAHKAMAH AGUNG NOMOR 2430K/PDT/2018)

Yenita Petriella, "Indonesia Kekurangan Tempat MICE Berstandar Internasional"

https://ekonomi.bisnis.com/read/20190214/12/888875/indonesia-

kekurangan-tempat-mice-berstandar-internasional. Diakses tanggal 19

Desember 2019. 